\title{
KEBIJAKAN MORATORIUM IKAN NAPOLEON (Cheilinus ndulatus Rüppell 1835)
}

\author{
Isa Nagib Edrus \\ Peneliti pada Balai Riset Perikanan Laut, Muara Baru-Jakarta \\ Teregistrasi I tanggal: 14 Desember 2010; Diterima setelah perbaikan tanggal: 16 Maret 2011; \\ Disetujui terbit tanggal: 23 September 2011
}

\begin{abstract}
Abstraks
Tulisan ini bertujuan untuk memberikan masukan bagi kebijakan perlindungan jenis ikan rawan punah, seperti ikan Napoleon. Tulisan ini diharapkan dapat bermanfaat bagi Kementerian Kelautan dan Perikanan dalam mempertimbangkan inisiatif moratorium penangkapan ikan tersebut. Metode penulisan menggunakan analisis kebijakan publik. Pertimbangan moratorium antara lain adalah bahwa perikanan Napoleon mengalami krisis karena lebih kapasitas usaha, lebih tangkap dan cara penangkapannya yang merusak, sementara kebijakan pengelolaan ikan Napoleon tidak kondusif dari sisi lingkungan hidup, hukum dan penegakan hukum. Lebih jauh statusnya sudah digolongkan rawan punah oleh UNEP dan dibutuhkan pengelolaan yang lebih berhati-hati. Ketidak-beruntungannya adalah telah terjadi penangkapan ilegal dan tidak terdata dalam sistem transpotasinya. Kuota penangkapan ikan Napoleon hanya mengatur perdagangan global, tetapi peraturan pengelolaan yang bersifat domestik membutuhkan aturan yang lebih serius untuk menyelamatkan ikan Napoleon dari kepunahan. Inisiatif perlindungan jenis satwa rawan punah memiliki dasar hukum hingga disarankan untuk menetapkan moratorium berjangka. Sosialisasi merupakan langkah penting untuk mendapatkan penerimaan masyarakat atas moratorium. Monitoring dan evaluasi merupakan bagian siklus dari moratorium untuk melihat kemajuan dan perbaikan manajemen.
\end{abstract}

\section{KATAKUNCI: ikan napoleon, kebijakan publik, moratorium}

\section{ABSTRACT: Policy synthesis of moratorium for humphead wrasse (Cheilinus undulatus). By: Isa Nagib Edrus}

This paper is aime to make a sinthesis of policy of endangered species protection, such as Hump Head Wrasse (HHW). This will be usefull for the Ministry for Marine and Fishery to decide a moratorium inisiative for the fish. A method used is the publicpolicy analysis. Some of judgements for making moratorium are that HHW fisheries were under crisis condition due to over capacity, over fishing and destructive fishing, while Napoleon fishery management was being worse for circumstances of living environment, law and law enforcement. Furthermore, HHW was listed in endanger species by UNEP and needed to carefully management. Unfortunatelly, it was happened the IIlegal, Unregulated and Unmonitored (IUU) fishing. Napoleon Fishing quota was only for global market regulation; however, domestically management regulation was needed a serious protocol to keep Napoleon save from losses. More protective manner for endanger wilds have the regulation willing to use in decision making for moratorium. Moratorium translations for publics are potential suggestion to get social acceptances and understanding. Monitoring and evaluation include in moratorium cyclus to identity progress and improve management.

KEYWORDS: $\quad$ hump head wrasse, public policy, moratorium

Kosrespondensi penulis:

Jl. Muara Baru Ujung, Komp. Pelabuhan Perikanan Samudera Indonesia

Jakarta Utara-1440. Tlp. (021) 6602044 


\section{PENDAHULUAN}

Keanekaragaman adalah aset untuk pembangunan dan kemakmuran bangsa, sementara aset ini tidak mudah untuk dikelola dan bahkan belum dimengerti dengan baik. Sebegitu jauh keanekaragaman dianggap sebagai suatu sumber daya yang dapat dieskploitasi dengan mudah dan sedikit sekali perhatian pada kelestariannya (Bappenas, 2003). Sementara keanekaragaman sumber daya ikan karang yang tinggi dari sisi jenis seringkali tidak diikuti oleh kelimpahan dari sisi individual (Arief \& Edrus, 2010). Oleh karena itu, ketika suatu jenis memiliki nilai ekonomis tinggi di pasar global dengan permintaan yang tinggi, maka pengelolaan menjadi dibatasi oleh nilai kelimpahannya di alam. Contohnya adalah ikan Napoleon (Cheilinus undulatus). Ancaman utama pada perdagangan ikan hidup Ikan Napoleon adalah lebih tangkap dan pengaruh cara penangkapan yang merusak terhadap ikan target lain, ikan non target dan lingkungan terumbu karang (Donaldson \& Sadovy, 2001; Gillett, 2010).

Sejak tahun 1990an, ikan Napoleon menjadi komoditas unggulan dalam ekspor perikanan asal Indonesia, karena wilayah perairan karang Indonesia menjadi habitat potensialnya (Sadovy et al., 2003). Pertama sekali hal ini dianggap sebagai suatu anugrah bagi mendukung pertumbuhan ekonomi dan peningkatan kesejahteraan masyarakat nelayan. Namun dampak negatif dari perikanan Napoleon kemudian menjadi isu penting dalam kelestarian terumbu karang, karena cara penangkapannya yang tidak ramah lingkungan dan menimbulkan eksternality bagi usaha lain. Untuk menanggulangi kasus-kasus kerusakan karang yang semakin sporadis, pemerintah melarang penangkapan ikan Napoleon atas dasar ekses kerusakan habitat yang ditimbulkan oleh penangkapan yang merusak. Larangan mengacu pada Peraturan Pemerintah Nomor 9 tahun 1985 dan Nomor 375/Kpts/ IK.250/5/95 yang ketika itu Dirjen Perikanan masih di bawah Deptan. Menteri Perdagangan pada tahun yang sama juga mengeluarkan keputusan Nomor : 95/EP/ V/95 tanggal 21 Mei 1995 yang berisi tentang larangan ekspor ikan Napoleon, kecuali atas izin Menteri Pertanian. Kebijakan pemerintah baru kemudian berpihak pada kepentingan pengaturan pengelolaan yang ramah lingkungan, setelah kasusnya menjadi perhatian dunia, terutama setelah diperkenalkan isu kuota penangkapan. Kebijakan terakhir terkait dengan Deklarasi Dirjen Perikanan No. HK.330/S3.6631/96 mengenai perubahan keputusan Dirjen Perikanan No. HK.330/ Dj.8259/95 tentang ukuran, lokasi dan tata cara penangkapan ikan Napoleon. Namun regulasi ini dipandang belum efektif ketika kemudian isu perikanan Napoleon berkembang ke arah tanpa kontrol, karena adanya kasus perdangangan bersumber dari perikanan IUU (IIlegal, Unregulated and Unmonitored). Dalam perjalanan waktu, regulasi-regulasi tersebut kemudian dianggap usang walaupun belum dicabut secara resmi, karena situasi semakin berkembang.

Setelah terbentuknya Kementerian Kelautan dan Perikanan, status populasi ikan Napoleon menjadi perhatian dunia setelah jenis itu yang berasal dari Indonesia membanjiri pasar global, sebagai pertanda maraknya IUU. Akhirnya di tahun 2004 semua ketentuan atau regulasi ikan ini masuk dalam tinjauan CITES dan Appendix 2 yang lebih berkenaan dengan tata aturan perdagangan di tingkat global, di mana aturan dinisbahkan pada kepentingan aturan panen yang tidak merugikan demi kesinambungan produksi (non-detrimental finding-NDF). Untuk kepentingan itu ditetapkanlah kuota perdagangan Ikan Napoleon di bawah tanggung jawab LIPI 
sebagai Scientific Authority dan Kementerian Kehutanan sebagai Management Authority. Sementara aturan ke dalam untuk membenahi pengelolaan ini secara umum mengacu pada UU 31/2004 dan UUD 45/2009 tentang perikanan dan pengawasan, larangan, dan sangsi. Keberuntungannya adalah bahwa ketentuan CITES tersebut masih membuka kuota perdagangan dan belum ditetapkan statusnya menjadi Appendix I bagi ikan Napoleon. Kuota perdagangan ikan Napoleon, seperti terlihat pada Tabel 1, menunjukkan angka yang semakin menurun dan angka realisasi kuota yang semakin kecil, namun hal ini belum dapat menjadi patokan resmi atas pemanfaatan ikan Napoleon. Dua hal yang menjadi perhatian tentang mengapa kuota semakin kecil dan realisasi ekspor juga menurun. Pertama, populasi ikan Napoleon di alam memang sudah menurun drastis menuju collapse seperti beberapa hasil penelitian (Donaldson \& Sadovy, 2001) dan diakui bahwa penangkapan dan perdagangan telah menurun $50 \%$ dalam kurun waktu $10-15$ tahun terakhir (Sadovy, 2006). Kedua, sekali lagi maraknya IUU masih menjadi batu sandungan dalam pengelolaan perikanan Napoleon, sehingga terkesan kuota tidak bermanfaat lagi ketika perdagangan gelap tidak tercatat.

Inisiatif terakhir adalah penegakan Peraturan Menteri Kelautan dan Perikanan Nomor PER.03/MEN/2010, tentang tata cara penetapan status perlindungan jenis ikan. Diharapkan ketetapan ini menjadi pintu masuk bagi perlindungan ikan yang terancam punah, seperti ikan Napoleon, dan sekaligus menjadi pedoman dalam penentuan kebijakan lebih lanjut.

Lebih jauh dunia melihat bahwa meskipun Undang-Undang, regulasi dan keputusan menteri telah siap menghadapi perikanan Napoleon, tetapi kerangka kerja kebijakan untuk pengelolaan panen, perdagangan domestik, dan ekspor ikan Napoleon belumlah dilaksanakan secara efektif. Karena tidak ada dokumen komprehensif yang mendeskripsikan seluruh regulasi pemerintah yang mengatur industri, stakeholders terlihat bingung dan gamang menghadapi ketetapan yang sudah ada. Kebingungan seperti ini juga menjadi umum di kalangan nelayan, pengumpul, eksportir dan bahkan pada tingkat subseksi dalam lingkup Kementerian Kelautan dan Perikanan dan tingkat pemerintah daerah. Saat ini dirasakan sekali kurangnya protokol yang terstruktur dan komprehensif dalam mengatur cara-cara yang dengannya terjadi penguatan otoritas untuk memantau, menegakan, dan mengeluarkan izin sehubungan dengan ikan Napoleon. Juga, terlihat adanya kelemahan dalam kerjasama antara PHKA, Balai Koordinasi Sumber Daya Alam, dan Kementerian Kelautan dan Perikanan dengan lembagapemantau dan penegakhukum yang relevan, seperti Bea Cukai dan Lembaga Karantina KKP (IUCN, 2006).

Tabel 1. Kuota perdagangan ikan Napoleon menurut tahun.

Table 1. Quota for Napoleon Trade by years.

\begin{tabular}{|c|c|c|c|c|}
\hline No & $\begin{array}{l}\text { Tahun } \\
\text { (Years) }\end{array}$ & $\begin{array}{l}\text { Kuota } \\
\text { (Quota) }\end{array}$ & $\begin{array}{c}\text { Realisasi } \\
\text { (Realization) }\end{array}$ & $\begin{array}{c}\text { Sisa } \\
\text { (Rest) }\end{array}$ \\
\hline 1 & 2005 & 8.000 & 5.320 & 2.680 \\
\hline 2 & 2006 & 8.000 & 5.970 & 2.030 \\
\hline 3 & 2007 & 8.000 & 6.228 & 1.772 \\
\hline 4 & 2008 & 7.200 & 3.809 & 3.391 \\
\hline 5 & 2009 & 8.000 & 4.220 & 3.780 \\
\hline 6 & 2010 & 5.400 & 3.810 & 1.590 \\
\hline 7 & 2011 & 3.600 & 970 & 2.630 \\
\hline Uim & & ). & $\begin{array}{l}\text { ktorat } \\
\text { nekaraga } \\
\text { nenterian }\end{array}$ & $\begin{array}{l}\text { nserv } \\
\mathrm{Ha} \\
\text { hutal }\end{array}$ \\
\hline
\end{tabular}

Untuk alasan itu timbul suatu area yang diistilahkan sebagai "wilayah abu-abu" (Tampubolon, 2011) yang dapat didefinisikan 
dalam segala pengertian, yakni mulai dari tidak terurus sampai salah urus, mulai dari belum terkendali sampai salah kendali, sehingga kasus-kasus IUU dapat berkembang subur di wilayah abu-abu seperti itu. Terlebih lagi regulasi pengganti Kepmentan tersebut belum disusun. Menghadapi kasus-kasus seperti ini, isu moratorium dari berbagai stakeholder untuk ikan Napoleon kemudian muncul, meskipun disadari bahwa moratorium belum menjadi jaminan secara pasti dapat mengatasi kasus-kasus IUU. Namun moratorium hanya akan mencapai target jika dipertimbangkan secara matang melalui analisis kebijakan publik. Peraturan Menteri Kelautan dan Perikanan Nomor PER.03/ MEN/2010 tetang Tata Cara Penetapan Status Perlindungan Jenis Ikan telah memberikan landasan yang kuat dalam melakukan inisitif terhadap perlindungan ikan Napoleon, yaitu salah satunya adalah melalui analisis kebijakan.

Tujuan penulisan sintesa kebijakan ini adalah untuk memberikan rekomendasi perlindungan jenis ikan Napoleon yang diharapkan dapat bermanfaat bagi Menteri Kelautan dan Perikanan dalam mempertimbangkan inisiatif moratorium ikan tersebut.

\section{BAHAN DAN METODE}

Pendekatan yang digunakan adalah analisis kebijakan publik (Simatupang, 2003), yaitu cara atau kegiatan menformulasi beragam informasi terkait yang relevan dan termasuk juga hasil penelitian untuk menghasilkan rekomendasi kebijakan publik. Kebijakan publik yang dimaksud adalah keputusan atau tindakan pemerintah yang berpengaruh terhadap hajad hidup orang banyak.

Cara kerja dalam pengumpulan informasi tersebut mencakup desk study dan konsultasi publik, seperti telah dilakukan beberapa kali pertemuan tahun 2010 - 2011 di Direktorat Jenderal Kelautan dan Pesisir Pulau Pulau Kecil, Kementerian Kelautan dan Perikanan. Kemudian atas informasi yang tersedia dilakukan sintesa ilmiah yang menyangkut studi kelayakan untuk opsi kebijakan dari sisi (1) hukum, (2) administratif, (3) politis, (4) biologi, (5) manajemen perikanan, (6) lingkungan, dan (7) sosial ekonomi.

\section{HASIL DAN PEMBAHASAN}

\section{Pembangunan Berkelanjutan}

Penentu kebijakan akan berhadapan pada dua kepentingan sekaligus, yaitu kepentingan ekonomi versus ekologi. Jalan tengah yang dapat menjadi patokan adalah amanat UU No.3 tahun 2002 tentang Pertahanan Negara, Bab I pasal 21 menyebutkan bahwa pendayagunaan segala sumber daya alam dan buatan harus memperhatikan prinsip-prinsip berkelanjutan, keragaman, dan produktivitas lingkungan hidup. Oleh karena itu jika konsep pembangunan berkelanjutan dipahami dengan baik, maka moratorium ikan Napoleon dapat diadaptasi tanpa keluar dari ide dasar dalam pembangunan yang berkelanjutan. Seperti diamanatkan dalam konsep pembangunan yang bekelanjutan bahwa pembangunan ekonomi tidak diharapkan berakhir pada hilangnya keanekaragaman jenis atau genetis. Kesimpulannya adalah adanya program perlindungan jenis dan genetik menjadi strategi alternatif untuk pemanfaatan yang berkelanjutan.

\section{Ikan Napoleon Jenis Rawan Punah}

Dalam pertumbuhannya ikan ini melalui beberapa fase pertumbuhan, dimana bentuk juwana, dewasa dan tua yang berbeda dari segi bentuk dan corak warna. Ikan Napoleon 
memiliki laju rekruitmen rendah karena pertumbuhannya lambat dan reproduksinya rendah (Sadovy et al, 2003). Pada tempat budidaya kecepatan tumbuh 3 inci dalam waktu 5 bulan (Sim 2004). Ikan Napoleon dewasa hidup soliter di terumbu karang, tempat di mana ikan ini memijah dan mobilitasnya rendah karena jarang pergi jauh dari tempatnya pemijahannya (Domeier \& Colin, 1997). Penyelampenyelam peneliti jarang menemukan ikan ini dalam kelompok besar, di mana kawanan ikan juwana di luar musim reproduksi terlihat antara 3 -5 ekor. Ketika musim reproduksi mungkin akan lebih besar kelompoknya, seperti yang ditemukan di Palau antara 12 - 75 ekor (Anonimous, 1992). Sediaan ikan Napoleon saat ini di alam tergolong sangat jarang. Beberapa hasil survei, seperti yang dilakukan IUCN dan LIPI tahun 2005 dan 2006 berkisar antara 0,4 sampai 0,86 ekor/ ha dengan total lokasi sampling $125 \mathrm{~km}$, yang meliputi Bunaken, Raja Ampat, NTT, Bali dan Kangean (IUCN, 2006) serta survei Bakosurtanal di 116 titik transek yang menyebutkan bahwa sediaannya bervariasi antara 0,5 sampai 2,6 ekor/ha dengan tingkat kelimpahan jarang (Edrus, 2010), seperti rendahnya frekuensi kemunculannya di setiap wilayah sensus (Tabel 2). Kondisi biologis, perilaku dan sediaan ikan Napoleon seperti ini jelas tidak menguntungkan bagi populasi Ikan Napoleon di alam untuk berkembang, terlebih-lebih ketika ikan ini diburu dengan cara penangkapan yang merusak.

Tahun 2004 merupakan tahun titik balik dalam pembenahan pengelolaan ikan rawan punah seperti ikan Napoleon, di mana CITES merasa perlu menetapkan regulasi berkenaan dengan perdagangan ikan ini pada pasar dunia. Melalui aturan main dalam perdangan bebas, dunia internasional merasa perlu mengontrol segala sesuatu yang berkenaan dengan erosi genetik dan ancaman pada kepunahan satwa sampai kepada cara pengelolaan sumber daya. Suatu hal yang memang tidak bisa kita elakan dan patut direspon dengan tindakantindakan internal ke dalam untuk mengelola ikan Napoleon. CITES (2004) menyebutkan bahwa semua informasi yang berasal dari data perikanan, hasil sensus bawah laut, laporan nelayan, laporan operator penyelam, dan semua laporan itu secara kolektif menunjukkan pertumbuhan populasi ikan Napoleon akhir-akhir ini menurun pada semua lokasi penelitian.

Pada tahun 2000an kelompok spesialis peniliti ikan kerapu dan ikan Napoleon di bawah kontrak sekretariat CITES telah melakukan survei dan pengkajian stok bersama LIPI. Hasilnya adalah bahwa ikan Napoleon dinyatakan berstatus rawan punah (Donaldson \& Sadovy, 2001; IUCN, 2006; Sadovy et al., 2003). Atas dasar itu pada tahun 2005 kuota perdangan ikan Napoleon ditetapkan. Selanjutnya annual kuota dapat bersifat adaptif bergantung pada informasi yang tersedia.

Kenyataan-kenyataan yang timbul kemudian adalah bahwa meskipun kuota telah ditetapkan dan kuota tersebut ternyata menurun sesuai dengan hasil monitoring (Tabel 1). Hal ini membuktikan bahwa ikan Napoleon benar-benar bersifat rawan punah dan diperparah oleh kasus-kasus IUU fishing. Perlindungan ikan Napoleon dalam status yang demikian membawa kepada suatu konsekuensi, yaitu perlu adanya pembatasan pemanfaatannya untuk memberi kesempatan perkembangan populasinya. Jenis-jenis satwa rawan punah perlu mendapat perhatian khusus karena stoknya di alam dianggap tidak mampu lagi menciptakan rente ekonomi manakala populasi ikan ini tertekan dan punah. 
Tabel2.

Table 2.

Sediaan, stadium, dan frekuensi kemunculan ikan Napoleon pada area sensus Stock, stadium, and appearing frquency of Humphead Wrasse in cencus areas

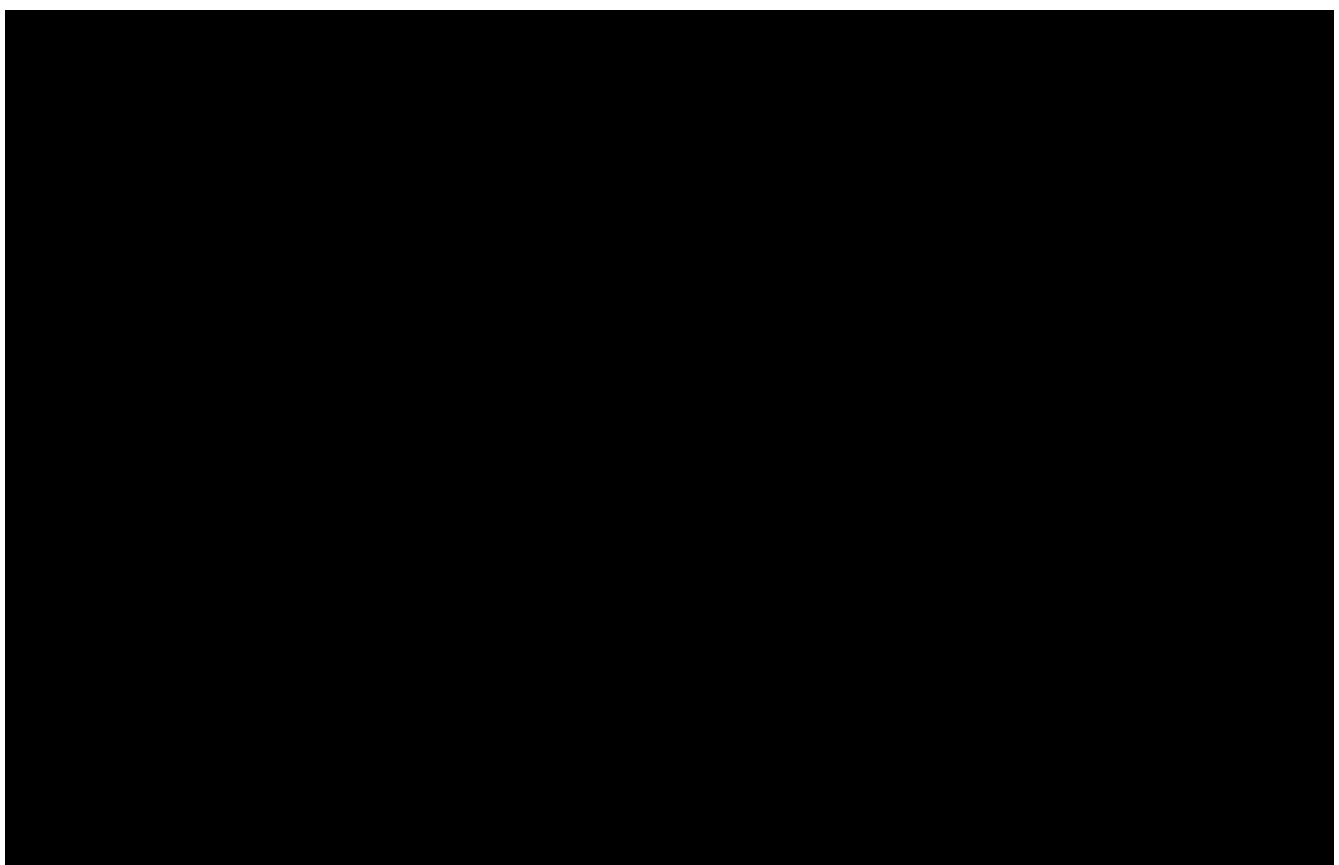

Sumber (Sources): diolah dari (modified from) Saputro \& Edrus, 2008; Edrus, 2010; Edrus et al., 2010; Edrus \& Setyawan, 2011; Setyawan \& Edrus, 2011; Edrus \& Suhendra, 2007

Kesenjangan antara sistem produksi dan prinsip kehati-hatian

Pemanfaatan sumber daya yang terancam kepunahan harus dilakukan dengan cara-cara bijak, dan didasarkan pada prinsip kehati-hatian. Semua ketentuan yang mengatur hal-hal tersebut sudah menjadi peraturan pemerintah, tetapi cenderung dipandang sebagai suatu regulasi pengelolaan perikanan yang normatif belaka.

Penerapan teknologi penangkapan dan cara penangkapan yang ramah lingkungan dalam beberapa hal sulit diimplementasikan di lapangan, karena animo masyarakat perikanan masih cenderung pada cara-cara penangkapan merusak, di mana mereka lebih familiar dan merasa diuntungkan dengan cara-cara merusak tersebut.
Penangkapan ikan dengan peladak dan racun sianida sudah menjadi hal biasa dan kebiasaan tersebut sudah semakin meluas terjadi dalam penangkapan di wilayah perairan karang tanpa dapat dipantau dan dilarang (Pet-Saode et al., 1996; Hopley \& Suharsono, 2000). Ancaman kerusakan karang di Asia Tenggara diperkirakan sebesar $64 \%$ berasal dari penangkapan berlebih dan $56 \%$ dari kegiatan penangkapan yang merusak (Burke et al., 2002).

Kebutuhan ekonomi jangka pendek, keserakahan, lemahnya regulasi dan belum optimalnya pelaksanaan pengawasan merupakan kondisi faktual yang sekarang umum dijumpai di lapangan. Semua ini menjadi sesuatu yang kontradiktif terhadap eksistensi UU No. 31 tahun 2004 tentang Perikanan dan Undang-Undang 
perubahannya No. 45 tahun 2009 serta Peraturan Pemerintah Nomor 60 tahun 2007 tentang Konservasi Sumber Daya Ikan. Sampai dengan saat ini regulasi tersebut belum dapat berjalan secara efektif dan upaya penegakan hukumnya pun masih belum berjalan dengan baik, serta seolaholah terjadi pembiaran. Pembiaran yang terjadi dalam jangka panjang akan membawa kepada kepunahan ikan Napoleon.

Kegiatan penyadaran masyarakat, pengawasan dan penegakan hukum merupakan salah satu kunci utama dalam pelaksanaan Non-Detrimental Finding (NDF) yang diamanatkan UNEP untuk penangkapan ikan Napoleon di Indonesia. Intisari dari apa yang dikehendaki oleh NDF adalah kehati-hatian dalam pengelolaan sumber daya rentan punah. Semua anasir pengguna sumber daya diminta untuk menciptakan cara-cara panen yang tidak merugikan. Ketidak-beruntungannya adalah bahwa, pada tingkat pengguna sumber daya sulit diberikan pengertian tentang konsep NDF tersebut. Rata-rata nelayan kita berpendidikan rendah dan miskin. Pada tingkat pengawas, sampai dengan saat ini kegiatan pengawasan dan pengendalian baru dilakukan di jalur-jalur peredaran resmi, sedangkan pelanggaran-pelanggaran yang ada di lapangan masih belum optimal dari segi tindakan penegakan hukum dan pemberian sangsi. Dalam beberapa tahun ke depan, kemampuan pengawasan yang dimiliki petugas lapangan dan ketersediaan sarana prasarana diprediksi akan kalah tanding dengan pelaku-pelaku IUU fishing yang semakin canggih, terorganisir dan dengan cara-cara yang semakin merusak (Tampubolon, 2011). Dengan mempertimbangkan aspek-aspek tersebut, kelemahan SDM dan sistem pengawasan, pemberhentian sementara kegiatan penangkapan merupakan solusi yang tepat untuk menekan ancaman kepunahan ikan
Napoleon di Indonesia, sampai menunggu pulihnya kesadaran masyarakat tentang perbaikan sistem produksi dan pulihnya populasi ikan Napoleon di alam.

\section{Ketidak pastian penerapan hukum yang menjadi dilema}

Substansi undang-undang pengelolaan sumber daya sering mengatur beberapa bidang persoalan secara seksama, jelas dan konfrehensif untuk melengkapi kebutuhan (Sumardiman, 2002). Tetapi, pada penerapannya di tingkat lapang, baik penegak hukum maupun pengawas masih terbentur pada kegamangan dalam penggunaan substansi-substansi pasalpasal hukum yang sudah jelas, khususnya dalam pembagian kewenangan dan tehnis pembuktian perkara serta antisipasi hal-hal yang bersifat laten.

Contohnya, Substansi regulasi pengelolaan ikan Napoleon yang pernah ditetapkan belumlah secara tegas menetapkan larangan atas penangkapan dan hanya mengatur tentang ukuran, lokasi dan tata cara penangkapan ikan Napoleon. Masalah aktual yang timbul kemudian adalah bahwa ukuran yang diperbolehkan oleh aturan justru stadium ikan-ikan Napoleon yang oleh peneliti dinyatakan sudah mulai mengandung telur, karena betina terkecil memijah di alam pada ukuran panjang total $35 \mathrm{~cm}$ (Gillett, 2010), sedangkan ikan Napoleon yang selama ini terjual di pasaran justru lebih banyak dalam stadium juwana yang berukuran antara 10 - 15 cm (IUCN, 2006; Sadovy, 2006), dan yang lebih tragis lagi adalah bahwa aturan tersebut masih memberikan akses pada pengumpul ikan Napoleon yang justru menggunakan nelayan-nelayan pengguna potasisum yang merusak. Semua ini tidak memberikan kepastian atas lestarinya sumber daya ikan Napoleon di alam. 
Kesulitan sering muncul bukan karena kurangnya pasal-pasal dalam substansi hukum yang digunakan terhadap perusak lingkungan, tetapi justru karena sulitnya menunjukkan bukti materiil. Dinamika perairan, seperti adanya gerakan massa air, yakni arus dan gelombang, dapat melenyapkan bukti-bukti materiil dalam hitungan menit sampai jam. Jika pemeriksaan terlambat, gradien dampak dapat berkurang atau mungkin menghilang karena arus kuat. Oleh karena itu, semua kasus pelanggaran perusakan lingkungan sebagai akibat cara-cara penangkapan ikan hidup dengan sianida atau potas sering tidak dapat ditindak-lanjuti dalam proses hukum, kecuali pelaku tertangkap basah. Pembuktian kasus seperti ini sering terbentur bukan saja pada saling lempar kewenangan tetapi juga pada banyaknya faktor dan ko-faktor yang bekerja atas kerusakan ekosistem karang, sehingga sulit dinisbahkan pada kejadian yang ditetapkan sebagai pengrusakan. Pembuktian juga bersandar pada dua pilihan yang belum tentu dapat diterima baik oleh pihak-pihak yang terlibat, yaitu apakah hanya semata-semata berdasarkan pada teori (scientific) atau hasil kerja pemerikasaan di tingkat lapangan atas kerusakan hingga menghasilkan bukti materiil. Yang kedua jauh lebih sulit dilakukan dari pada yang pertama, terlebihlebih jika kejadian pengrusakan sudah berselang lama dan akurasi datanya juga masih terbuka untuk didiskusikan, hingga memberikan peluang lolosnya pelaku pengrusakan.

Pada umumnya penangkapan ikan Napoleon dilakukan malam hari dan pada saat yang sama tidak ada petugas pengawas dan juga tidak ada petugas analis laboratorium di lokasi penangkapan tersebut. Ketika kemudian kapal pedagang ditemukan membawa hasil tangkapan tersebut, mereka hanya terjerat kasus pelanggaran penyalahgunaan dokumen SIKPI, sementara pelaku penangkapan yang merusak tidak terdeteksi. Ketika berhadapan dengan kejadian seperti ini, pengawas lapangan tidak pula dapat menggiring pelaku pencurian ikan ke meja hijau untuk memberikan efek jera sesuai dengan substansi UU 45 tahun 2009 atau PP 20 tahun 2007 karena beragam alasan (Tampobolon, 2011), kecuali merampas hasil tangkapan yang tidak sesuai ukuran, memberikan teguran keras dan melepaskan ikan Napoleon kembali ke habitatnya, sedangkan kerusakan lingkungan akibat cyanid fishing yang terjadi tidak ada berita acaranya dan tidak ada pula ada gugatan kerugian dari pihak pengguna lain. Mungkin hal ini yang dimaksud oleh Sadovy (2006) bahwa pemerintah masih terlampau lemah dalam pengawasan dan penegakan hukum.

Kasus seperti ini secara pasti jarang dipandang sebagai kasus kejahatan, karena sulitnya dalam pembuktian walaupun kelengkapan pasal-pasal undangundangnya tersedia. Paling tidak kasus ini hanya dipandang sebagai kasus eksternalitas biasa dalam rezim open access yang tidak pula diteruskan pada sanksi denda (economic sentence). Sekali lagi, untuk mempermudah dan menyederhanakan proses dalam usaha menyelamatkan ikan Napoleon perlu adanya langkah-langkah perlindungan yang lebih konkrit, seperti penetapan moratorium.

\section{Landasan hukum}

Perlindungan atas ikan Napoleon dapat mengacu pada Undang-Undang Nomor 31 tahun 2004 tentang Perikanan sebagaimana telah diubah dengan Undang-Undang Nomor 45 tahun 2009. Pasal 7 ayat 1 (u) menyatakan bahwa "dalam rangka mendukung kebijakan pengelolaan sumber daya ikan Menteri menetapkan jenis ikan yang dilindungi". Pada Pasal 7 ayat (6) 
disebutkan bahwa "Menteri menetapkan jenis ikan yang dilindungi dan kawasan konsevasi perairan untuk tujuan ilmu pengetahuan, kebudayaan, pariwisata, dan/ atau kelestarian sumber daya ikan dan/atau lingkungannya.

Peraturan Pemerintah Nomor 60 tahun 2007 tentang Konservasi Sumber Daya lkan dan Konservasi jenis ikan adalah upaya melindungi, melestarikan, dan memanfaatkan sumber daya ikan, untuk menjamin keberadaan, ketersediaan dan kesinambungan jenis ikan bagi generasi sekarang maupun yang akan datang (Pasal 21) dan konservasi jenis ikan dilakukan melalui penggolongan jenis ikan, penetapan status perlindungan jenis ikan dan pemeliharaan, pengembangbiakan, dan penelitian serta pengembangan.

Selanjutnya Peraturan Menteri Kelautan dan Perikanan Nomor PER-03/MEN/2010 memberikan dasar-dasar tentang Tata Cara Penetapan Status Perlindungan Jenis Ikan.

\section{Implikasi politis atas Undang-Undang}

Orientasi politik adalah untuk kepentingan rakyat maka kemakmuran rakyat adalah segala-galanya (UUD 1945 pasal 33 ayat 3) dengan tetap memperhatikan keseimbangan, kelestarian lingkungan dan sanksi hukum (UU no. 45 tahun 2009).

Penerapan Undang-Undang dan regulasi perikanan bukan berarti mempolitisasi perikanan untuk tendensi kepentingan tertentu atau sektor, namun untuk memperjuangkan pembangunan perikanan bagi kepentingan rakyat dan kelestarian sumber daya perairan. Dua frasa ini, yaitu "kepentingan rakyat" dan "kelestarian sumber daya", merupakan kunci politis untuk masuk pada usaha pembatasan pemanfaatan ikan Napoleon. Segala sesuatu yang berkenaan dengan "pembatasan pemanfaatan" sumber daya alam dapat menjadi pertengkaran dan digunakan sebagai alat politis yang justru membatasi fungsi-fungsi eksekutif dalam pengelolaan perikanan, di mana eksekutif dianggap telah melakukan pelanggaran terhadap undang-undang, meskipun pelestarian sumber daya alam juga diatur oleh undang-undang yang legal karena untuk kepentingan bersama.

Pembatasan pemanfaatan ikan Napoleon bukan berarti memperkosa hakhak ulayat, tetapi lebih kepada aturan bagaimana masyarakat dapat memanfaatkan ikan Napoleon dalam caracara yang baik dan bijaksana.

\section{Manajemen Perikanan}

\section{Lebih kapasitas dalam perikanan}

Seperti yang disinyalir oleh oleh Fauzi (2005), sumber utama krisis perikanan Napoleon adalah buruknya pengelolaan perikanan Napoleon yang ditunjukkan oleh dua hal yang menonjol, seperti lebih kapasitas (overcapacity) dan destruksi habitat (penggunaan potas).

Sumber daya ikan Napoleon bersifat dapat diperbaharui (renewable), tetapi bukan tidak mungkin akan menuju kepada kepunahannya (collapse), karena ketika laju ekstraksi ikan tersebut telah melebihi kemampuan regenerasinya, pasti akan terjadi perubahan dalam populasi.

\section{Destruksi habitat dan konsekuensinya dalam perikanan}

Meski situasi lebih tangkap di Indonesia relatif tidak sederastis pada skala global di banyak wilayah subtrofis, tetapi destruksi habitat justru sering menjadi masalah utama di wilayah negara berkembang yang disebabkan oleh kemiskinan dan lemahnya 
pengawasan. Destruksi ekosistem tercatat relatif tinggi pada negara-negara Asia, khususnya Filipina dan Indonesia (Burke et al., 2002). Untuk alasan ini sering kali negara-negara maju, baik sebagai donor maupun sebagai importir merasa harus campur tangan karena sumber daya ikan telah diklaim menjadi kepentingan dan keperihatinan Global. Privasi sumber daya perikanan melalui kuota akhirnya menjadi agenda global. Sebagai konsekuensinya adalah bahwa beragam kebijakan perikanan sering terbentur pada regulasi yang ditetapkan dalam perdagangan global. Issu environmental labelling, yang tercantum dalam Doha agenda pada pertemuan WTO ke-4 di Doha, Qatar, justru menjadi dilema bagi negara-negara berkembang, seperti Indonesia. Sekarang kita menghadapi kasus yang sama bahwa ikan Napoleon telah diberikan kuota yang tiap tahun akan dikaji terus untuk direvisi. Jika ingin masuk pada perdagangan global, mau tidak mau atau suka tidak suka, kita wajib berperan aktif untuk menunjukkan bahwa kita ramah dan perhatian penuh pada masalah degradasi ekosistem.

\section{Sifat buruk perikanan Napoleon}

Pengelolaan perikanan Napoleon saat ini sudah masuk pada kategori over eksploitasi dan merusak ekosistem karang (Sadovy et al., 2003; Sadovy, 2006; IUCN, 2006). Laporan WWF menyebutkan bahwa lebih dari 6000 penangkap ikan hidup telah menggunakan $150.000 \mathrm{~kg}$ potas dan dalam bentuk larutan disemprotkan ke 33 juta onggok karang setiap tahun. Jika praktik peracunan tersebut terus berlangsung, diperkirakan tahun 2020 semua terumbu karang akan rusak (Michael, 2011).

Pengelolaan ikan Napoleon yang berstatus rawan punah sudah harus dalam bentuk pembatasan penangkapan, yang bukan saja dalam bentuk penetapan kuota, tetapi juga dalam bentuk pelarangan penangkapan untuk memberikan kesempatan pada pertumbuhan populasinya di alam. Karakteristik di sektor perikanan Napoleon adalah unik, selain bersifat ordinary-rare resource (sejatinya adalah sumber daya yang terbatas), juga bersifat common property resource (sumber daya sebagai hak kepemilikan umum). Interaksi kedua faktor ini sering menimbulkan eksternalitas yang mendorong terjadinya lebih tangkap dan kemudian justru menimbulkan penurunan stok sumber daya dalam waktu yang pendek dan kemudian sulit untuk tumbuh kembali secara cepat (Burke et al. 2002).

Untuk alasan ini, penanganan masalah perikanan memerlukan pendekatan tersendiri. Pilihan yang terbaik bagi manajemen perikanan Napoleon di Indonesia adalah melakukan perubahan pundamental dari sekadar mengelola sisi suplai ke mengelola manusia sebagai pengguna, karena yang dikelola ini adalah sumber daya rentan punah dan penggunanya adalah penentu kebijakan yang buruk dan bahkan sekaligus perusak lingkungan (Salm et al., 2000). Dengan demikian, pembatasan total adalah langkah yang dianggap tepat dibanding penetapan kuota penangkapan. Selama ini kuota justru akan memberikan celah yang lebih besar pada ilegal fishing, sementara dengan pelarangan diharapkan akan lebih memudahkan pengawasan.

\section{Gangguan dari perikanan Napoleon}

Keuntungan ekonomi perikanan adakalanya tidak sepadan dengan ongkos yang ditanggung masyarakat dan lingkungan (environmental cost) yang memang tidak pernah diperhitungkan dalam analisa finansial tentang keuntungan bersih (Cesar, 1996; Pet-Soede et al., 1996). Terumbu karang di Indonesia menyediakan 
keuntungan ekonomi tahunan sebesar US $\$ 1,6$ juta (Burke et al., 2002), tetapi tidak sedikit pula kerugian yang ditanggung oleh ekosistem. Usaha individual perikanan yang menggunakan racun (sianid fishing) memperoleh keuntungan bersih 33.000 US $\$$ per $\mathrm{km}^{2}$ dalam periode 20 tahun, tetapi total kerugian yang ditimbulkannya bagi usaha masyarakat dalam perikanan tangkap yang berkelanjutan dan usaha pariwisata mencapai 40.000 sampai 446.000 US $\$$ per $\mathrm{km}^{2}$ dalam periode yang sama, di mana nilai tersebut belum terhitung kerugian dari sisi kehilangan biodiversitas dan proteksi lingkungan (Cesar, 1997; dalam Burke et al., 2002).

Contoh gangguan (eksternalitas) yang lebih spesifik adalah perikanan Napoleon di Wangi-Wangi, Kabupaten Wakatobi, Kendari. Perikanan Napoleon disinyalir menggunakan potas (Sianida) dan menimbulkan ekses pada perikanan kerapu hidup (Purnomo, 2009). Produksi kerapu antara 2009 sampai 2011, menurun sebagai akibat pengaruh perikanan potas (Gambar 1). Semua orang mengerti bahwa Wakatobi adalah salah satu area yang dilindungi (Taman Laut Nasional), tetapi kasus-kasus perikanan potas tidak dapat ditanggulangi.

\section{Dampak Ekonomi Perikanan Napoleon}

Secara ekonomi, pelarangan penangkapan ikan Napoleon tidak akan berpengaruh besar terhadap pendapatan masyarakat nelayan artisanal. Ikan Napoleon bukan menjadi target utama penangkapan bagi kebanyakan Rumah Tangga Perikanan (RTP). Rumah Tangga Perikanan Napoleon relatif kecil (Tabel 2) jika dibanding RTP perikanan secara umum.
Sedangkan jumlah eksportir ikan hidup Napoleon kurang lebih 15 perusahaan (Dirhamsyah, 2011). Moratorium terhadap penangkapan ikan Napoleon hanya akan berpengaruh pada perikanan padat modal dan eksportir (Tabel 3), karena justru mereka yang mendapat keuntungan terbesar.

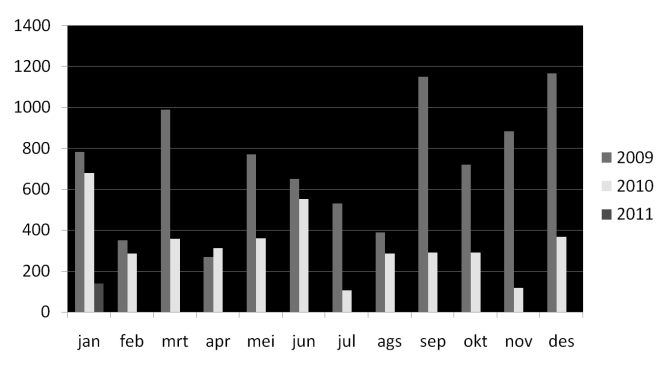

Gambar 1. Penurunan produksi ikan kerapu hidup akibat perikanan potas di WangiWangi,Wakatobi, Sulawesi Tenggara

Figure 1. Decreasing in live grouper production due to cyanide fishing in Wangi-Wangi, Wakatobi, Sulawesi Tenggara

Pelarangan penangkapan ikan Napoleon juga tidak akan berpengaruh signifikan terhadap kontribusi terhadap Penghasilan Nasional Bukan Pajak (PNBP) sektor perikanan, karena nilai PNBP hanya sekitar Rp. 48.000.000,-/tahun sesuai dengan besaran kuota. Pelarangan ekspor ikan Napoleon juga tidak berpengaruh secara signifikan terhadap nilai ekspor ikan karang Indonesia, karena proporsi ikan Napoleon kurang dari $10 \%$ dari total ekspor ikan karang (Ruchimat, 2011). 
Tabel2. Jumlah Rumah Tangga Perikanan yang khusus menangkap Ikan Napoleon.

Table 2. Fisherman household numbers that are specially in Napoleon fishing.

\begin{tabular}{lc}
\hline WILAYAH / Regions & JUMLAH / Totals \\
\hline Natuna & 100 \\
Banggai & 100 \\
Derawan & $79-90$ \\
Mentawai & 50 \\
Pulau Sembilan & 50 \\
Wakatobi & $20-30$ \\
Komodo & $20-30$ \\
Karimun Jawa & 0 \\
Bangka Belitung & 0 \\
\hline
\end{tabular}

\section{Keragaan Sistem Perikanan Napoleon}

Seperti dijelaskan di atas bahwa masalah utama krisis perikanan adalah tidak terkendalinya upaya (input) dari stakeholders dalam mengelola sumber daya ikan. Sejauh ini masalah-masalah perikanan sering bersifat latent atau tidak tanpak di permukaan sebagai suatu permasalahan krusial yang harus dipecahkan lebih dahulu. Sering kali program-program pembangunan perikanan berada di jalan buntu dan bahkan kontroversial dalam pelaksanaannya. Untuk membedah akar permasalahan dan kebijakan yang selama ini dirasa kurang tepat, Smith dan Link (Fauzi, 2005) menyarankan untuk melakukan "otopsi" terhadap perikanan agar kebijakan yang berbasis pada kegagalan masa lalu dapat ditetapkan.

Permasalahan perikanan secara sederhana adalah turunan dari dua faktor generik, yaitu penanganan sumber daya (termasuk pendugaan serta penilaian stok), dan penanganan "input" untuk mengekstraksi sumber daya (termasuk kapital, nelayan dan kebijakan dan sebagainya). Stok sangat bersifat dinamis dan mengharuskan kita mempelajari stok di masa lalu dan gangguan-gangguan yang menyebabkan perubahan stok di masa lalu. Gangguan pada stok di luar kendali manusia, sedangkan gangguan pada "input" berada sepenuhnya di tangan pengelola. Dengan demikian, masalah sumber daya bukanlah semata-mata masalah lingkungan melainkan masalah manusia yang timbul berulang-ulang di tempat yang berbeda dalam konteks politik, sosial dan sistem ekonomi yang berbeda pula. Selayaknya perumusan kebijakan yang tepat harus lebih dahulu diarahkan pada sisi tersebut (Salm et al., 2000 ; Fauzi, 2005). 
Tabel 3. Volume ekspor dan nilai ekspor ikan Napoleon asal Indonesia ke pasar Hongkong

Table 3. Export volumes and values of Napoleon fish coming from Indonesia to Hongkong market

\begin{tabular}{|c|c|c|c|c|c|c|}
\hline \multirow{2}{*}{ Parameter } & \multicolumn{6}{|c|}{ Tahun (Years) } \\
\hline & 2000 & 2001 & 2003 & 2004 & 2005 & 2006 \\
\hline $\begin{array}{l}\text { Volume ekspor (kg) } \\
\text { (Export Volumes) }\end{array}$ & 875 & 499 & 5344 & 2526 & 544 & 4619 \\
\hline $\begin{array}{l}\text { Kisaran Harga borongan di } \\
\text { pasar Hongkong } \\
\text { (Rank of Hongkong Market } \\
\text { Prices) - US \$/kg } \\
\text { Harga rata-rata }\end{array}$ & $45-70$ & $50-65$ & $50-70$ & $25-95$ & $27-111$ & $27-111$ \\
\hline $\begin{array}{l}\text { (Mean Price) - US } \$ / k g \\
\text { Rata-rata Nilai Ekspor } \\
\text { (Mean Export Value) - }\end{array}$ & 57,5 & 57,5 & 60 & 60 & 69 & 69 \\
\hline US \$ & 50.313 & 28.693 & 320.640 & 151.560 & 37.536 & 318.711 \\
\hline
\end{tabular}

Secara lebih tegas dapat dikatakan bahwa kegagalan masa lalu adalah kurang tanggapnya stakeholder terhadap sifat stok ikan Napoleon yang sudah jelas, di mana dalam situasi tanpa tekanan (tanpa eksploitasi), populasi ikan Napoleon di alam memang sudah memiliki sifat rendah kelimpahan dan kepadatannya. Hasil penilaian stok tidak pernah mendapat penghargaan yang layak. Pengguna terlampau berorientasi pada tingginya permintaan pasar dengan harga yang tinggi, sehingga dorongan peningkatan investasi tidak dapat dibendung. Di sisi lain ekploitasi yang tinggi dalam interval waktu yang rapat dan berjangka panjang tidak memberikan kesempatan proses regenerasi populasi ikan Napoleon. Akhirnya status normalnya yang "jarang" dan "sedikit" tadi menjadi terpuruk ke status rawan punah. Akibatnya CITES menetapkan status Appendix II untuk ikan Napoleon, sementara kajian mendalam untuk mengembangkan protokol penangkapan dan perdagangan yang komprehensif serta terkontrol tidak dilakukan. Hal ini berujung pada maraknya kasus-kasus IUU perikanan Napoleon. Kasus-kasus IUU tersebut jika tetap tidak terkendali akan kembali menjadi batu sandungan bagi industri perikanan Napoleon di Indonesia, di mana pada akhirnya akan berujung pada peningkatan status yang diterapkan CITES dari appendix II menjadi Appendix I.

\section{OPSI KEBIJAKAN}

\section{Membangun perhatian masyarakat}

Dalam asumsi pengelolaan yang efektif sebenarnya lebih bertumpu pada penanganan pengguna (untuk merubah sikap) dari pada hanya sekadar penanganan yang bertumpu pada kegiatan restologi, restocking, rehabilitasi, introduksi teknologi dan legislasi/regulasi.

Regulasi dapat diciptakan silih berganti dan begitu juga teknologi serta management tools, namun adaptasi dan penerimaan kontrol atas semua itu bergantung pada kemauan dan penerimaan masyarakat. Perhatian masyarakat (Public awareness) adalah kunci dari inisiatif keterlibatan masyarakat dalam perlindungan jenis ikan rawan punah. Masalah terberat di tingkat 
lapang dengan intensitas yang meluas di Indonesia adalah membangun situasi yang kondusif di antara hubungan usaha-usaha preventif dari pemerintah dan penerimaan masyarakat. Pemerintah diharapkan mampu membangun rasa saling percaya dan presiden yang baik jika ingin membentuk integritas masyarakat pada masalah lingkungan. Dalam hal ini masyarakat percaya bahwa mereka masih punya kesempatan mendapat profit dari keterlibatannya. Pemerintah memberikan contoh yang baik dalam penegakan hukum, terutama peran aparat keamanan di tingkat lapang merupakan aktor yang harus disegani, menjadi presiden yang baik dan bukan menjadi aktor perusak kesepakatan (korup) yang terbentuk hingga menjadi kontra produktif bagi pengelolaan sumber daya yang dianggap akan punah. Tidak diharapkan masyarakat menjadi pesimis dan apatis hanya karena tidak berjalannya penegakan hukum. Diharapkan kesungguhan penegakan hukum oleh pemerintah akan lebih mendorong integritas masyarakat untuk secara aktif sebagai mitra mencegah kerusakan lingkungan dan ilegal fishing.

\section{Mengembangkan protokol umum}

Pada tingkat pemerintah masalah yang mendesak adalah masalah tersedianya ketetapan holistik untuk mengatur perikanan Napoleon. Kebijakan di tingkat dunia semakin cepat berubah seiring dengan semakin cepatnya kerusakan ekosistem dan lingkungan hidup. Melalui moratorium semuanya diharapkan akan menjadi jelas dan meyakinkan, khususnya bagi pejabat pembuat kebijakan, pemberi izin, pengawas lapangan, penegak hukum, pengusaha perikanan dan nelayan untuk masingmasing sesuai fungsinya mengerti dan kemudian bersepakat menjaga ikan Napoleon dari kepunahan.
Semua produk legislasi perlindungan jenis ikan rawan punah (dalam hal ini moratorium) perlu tindakan-tindakan pengawalan. Pemahaman dan penerimaan masyarakat merupakan kunci keberhasilan atas perlindungan sumber daya (Salm et al., 2000). Masyarakat perlu diberi kesempatan untuk memahami alasan mengapa moratorium ditetapkan, sehingga mereka mampu membentuk regulasi yang bersifat tradisional dengan dasar-dasar ekologis menurut pengertian mereka sendiri.

\section{Mengantisipasi kegagalan moratorium}

IUU Fishing dapat dipastikan akan terus timbul sebagai konsekuensi negatif dari penetapan moratorium. Masa depan moratorium dalam menghadapi hal tersebut akan sangat bergantung pada integritas masyarakat dan kemauan politis aparat pengawas serta penegakan hukum. Tumpuan pada integritas masyarakat akan lebih menonjol jika memperhatikan keterbatasan pemerintah di tingkat lapang. Oleh karena itu, tipe moratorium harus lebih masuk akal menurut perhitungan untung rugi masyarakat dan bukan sekadar alasan ekologis semata-mata. Lebih jauh moratorium tidak boleh dijadikan sebagai alat kesepakatan politis yang menyimpang (KKN), karena akan menjadi beban dalam penegakan integritas masyarakat. Sinergitas antara masyarakat dan pemerintah harus terbentuk dalam operasional penegakan moratorium. Pemerintah perlu tetap memelihara kinerja dan citra yang baik (good governance) untuk membangun perhatian masyarakat.

\section{Moratorium terbatas}

Prinsip pembangunan yang berkelanjutan membawa kepada pengelolaan sumber daya yang lebih bijaksana dari sisi pemanfaatan sumber 
daya berkelanjutan sebagai akibat dari usaha-usaha menjaga kelestariannya. Pembatasan mutlak pada pemanfaatan sumber daya yang dapat diperbaharui akan menjadi paradoks bagi kesejahteraan masyarakat. Oleh karena itu, untuk kasus pemanfaatan ikan Napoleon perlu ditetapkan jalan tengah melalui perlindungan yang tidak menimbulkan kontrovesrsial.

Tipe perlindungan jenis selain penetapan kuota dan belum dicoba adalah moratorium. Moratorium pada dasarnya adalah larangan yang bersifat temporal. Penetapan moratorium disinyalir akan menghadapi banyak kritik bahkan perlawanan massa. Kemudian timbul inisiatif wacana moratorium terbatas yang sebenarnya telah berkembang sebelumnya di tengah masyarakat Maluku, yaitu praktek perlindungan jenis secara tradisional yang disebut "adat sasi". Perlindungan jenis ala moratorium terbatas mungkin lebih mudah diadopsi masyakat. Moratorium terbatas dapat diaplikasikan dalam dua pola, yaitu perlindungan secara spasial dan temporal. Perlindungan spasial, dalam hal ini adalah buka tutup wilayah tangkap ikan Napoleon, yaitu pada waktu tertentu ada wilayah tertutup yang ditetapkan, sementara wilayah lain terbuka untuk eksploitasi. Perlindungan temporal adalah larangan penangkapan di semua wilayah dalam waktu yang ditentukan. Perlindungan temporal seperti ini lebih mirip adat sasi di Maluku yang nampak sederhana tetapi efektif.

Namun pengalaman sebelumnya telah memberikan pelajaran bahwa peluang sekecil apapun dalam rezim open access akan menimbulkan pelanggaran terhadap ketentuan legislasi, karena dorongan ekonomi lebih dominan. Dengan demikian, pola perlindungan jenis secara spasial menjadi tidak ideal ketika diperuntukan untuk jenis ikan bernilai ekonomis tinggi seperti ikan Napoleon dan bahkan tetap akan menimbulkan kesulitan dalam pengawasannya.

Pola perlindungan jenis secara temporal dianggap akan mempermudah sistem pengawasan dalam rentang waktu yang ditentukan, sehingga perlu dicoba dan disosialisasikan untuk menyelamatkan ikan Napoleon dari kepunahan. Moratorium terbatas hendaknya menjadi konsensus nasional yang kemudian dapat diadopsi oleh masyarakat menjadi aturan-aturan adat yang lebih bisa diterima mereka.

Penangkapan ikan Napoleon seperti dijelaskan di muka telah menjadi masalah dalam 10 - 15 tahun sebelumnya, di mana produksi menurun hingga $50 \%$ sementara status kepadatan ikan Napoleon di alam saat ini rata-rata kurang dari 2 ekor/ha. Moratorium temporal terbatas dapat mengacu pada waktu 10 sampai 15 tahun, untuk kemudian dievaluasi setelahnya dengan indikator kepadatan yang meningkat melebihi 4 ekor/ha untuk penghapusan moratorium.

\section{Alternatif yang lebih menguntungkan}

Opsi moratorium adalah yang paling strategis untuk kepentingan menyelamatkan jenis ikan rawan punah, habitatnya dan lingkungan hidup organisma laut serta mempermudah pengawasannya. Moratorium penangkapan ikan Napoleon akan menempatkan ikan itu sendiri sebagai objek material pembuktian pelanggaran hukum, karena telah menjadi benda terlarang untuk ditangkap. Dengan adanya moratorium maka pekerjaan-pekerjaan pengawasan dan pembuktian yang dianggap rumit menjadi lebih disederhanakan.

Keuntungan lain dari moratorium adalah bahwa moratorium dapat menimbulkan isu lain yang akan menempatkan ikan Napoleon menjadi objek menarik sebagai 
hewan langka dan pada akhirnya akan menarik dalam wisata bahari. Laporan Gillett (2010), ikan Napoleon yang biasa disebut "Wally" oleh penyelam lokal Australia ternyata dapat diajak bermain dan mudah didekati (friendly) oleh penyelam-penyelam di Norman Reef of Australian's Geret Barrier Reefs (Gambar 2). Untuk alasan itu, pengembangan ekonomi wilayah, dimana ikan Napoleon ditemukan, pasti akan terjadi apabila wilayah tersebut dipromosikan sebagai area tujuan wisata penyelampenyelam domestik maupun dunia untuk bermain dengan ikan Napoleon, seperti kasus yang sama untuk ikan mola di wilayah Nusa Penida Bali. Banyak pendapatan alternatif akan diperoleh melalui pengembangan Napoleon Dive Cruise.

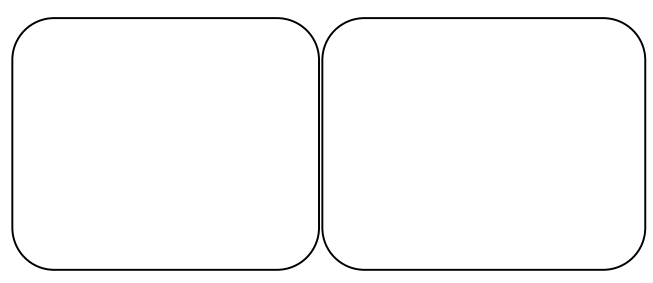

Gambar 2. Keuntungan lain dari ikan Napoleon sebagai objek wisata bahari

Figure 2. Further benefits of Napoleon fish in terms of marine tourism

Sumber (Source): http://ikanmania. wordpress.com

Moratorium bukan saja dapat memberikan kesempatan perkembangan populasi ikan Napoleon di alam, tetapi juga merangsang usaha-usaha budidayanya (hatchery) yang mulai dirintis dan berhasil dilakukan oleh Balai Besar Budidaya Ikan di Gondol, Bali (Sim, 2004).

\section{KESIMPULAN DAN REKOMENDASI KEBIJAKAN}

\section{Kesimpulan}

Beberapa hal yang dapat disimpulkan bagi penentu kebijakan antara lain adalah :

1) Perikanan Napoleon mengalami krisis yang ditunjukkan oleh dua sifat yang menonjol, seperti intensitas penangkapan yang tidak memberikan kesempatan pada perkembangan stoknya di alam dan cara penangkapan yang merusak habitat dan lingkungan hidup ikan, hingga berdampak buruk pada usaha perikanan karang berkelanjutan dan pariwista.

2) Kebijakan pengelolaan ikan Napoleon tidak kondusif dari sisi substansi legislasi dan efektifitas pengawasan dan penegakan hukum, seperti ditunjukkan oleh maraknya IUU fishing.

3) Respon dunia dalam hal status ikan Napoleon sebagai rawan punah (Appendix II) bersifat positif hingga timbul inisiatif NDF, tetapi respon perdagangannya negatif karena mendorong eksploitasi tidak terbatas yang tidak selaras dengan ide NDF.

4) Kuota perdagangan ikan Napoleon sebagai upaya perlindungan jenis rawan punah hanya mengakomodasi dan mengatur pada tingkat perdagangan global, tetapi peraturan pengelolaan yang bersifat domestik membutuhkan peraturan lebih serius untuk menyelamatkan ikan Napoleon dari kepunahan.

5) Inisiatif perlindungan jenis satwa rawan punah telah memiliki mandat tetap melalui Peraturan Menteri Kelautan dan Perikanan Nomor PER.03/MEN/2010.

\section{Rekomendasi}

Rekomendasi bagi penentu kebijakan antara lain : 
1) Perlu menetapkan perlindungan ikan Napoleon dengan cara pelarangan penangkapan selama rentang waktu 10 sampai 15 tahun.

2) Perlu melakukan sosialisasi yang berkenaan dengan pelarangan tersebut dan melibatkan masyarakat dalam mentranslasi ketentuan moratorium ke dalam bentuk yang mudah difahami dan diterima masyarakat.

3) Perlu melakukan monitoring berkala populasi ikan Napoleon selama berlakunya moratorium dan melakukan evaluasi summatif pasca berakhirnya ketetapan moratorium.

4) Perlu melakukan propaganda pariwisata dengan tema "Indonesian Dive Cruise Year for Napoleon Fish".

\section{DAFTAR PUSTAKA}

Anonimous. 1992. Palau Fishery Report, Annual report. Division of Marine Resources. Bureau of Natural Resources and Development. Ministry of Resources and Development, Koror, Palau, 99 pp.

Arief, S. \& I.N. Edrus. 2010. Struktur Komunitas Ikan Karang di Perairan Karang Kabupaten Maluku Barat Daya. Jur. Pen. Perikanan Indonesia Vol 16 (3): $235-250$.

BAPPENAS. 2003. Indonesian Biodiversity Strategy and Action Plan. NATIONAL DOCUMENT. The National Development Planning Agency.

Burke, L., E. Selig \& M. Spalding. 2002. Reefs at Risk in Southeast Asia. World Resources Institute, Washington DC. 76 pp.

Cesar, H. 1996. "Economic Analysis of Indonesian Coral Reefs," Working Paper Series 'Work in Progress', Washington, $D C$ : World Bank.
CITES. 2004. Amendments to Appendices I and II of CITES [proposal]. Convention on the International Trade in Endangered Species, 13th Meeting of the Conference of the Parties.

Dirhamsyah. 2011. Study on Fisheries Management of Napoleon Wrasse in Indonesian Waters. P2O-LIPI's Working Paper dalam: "Temu Pakar Penyusunan Rencana Aksi Pengelolaan Jenis Ikan Napoleon Wrasse (Cheilinus undulatus), di Blue Sky Pandurata Hotel, Jakarta, 11 Agustus 2011, KKJI - KKP (Published in print)

Domeier, M.I. and P.L. Colin. 1997. Tropical reef fish spawning aggregation defined and revieuwed. Bull. Mar. Sci. 60(3), 698726.

Donaldson, T. J. \& Y. Sadovy. 2001 Threatened Fishes of The World : Cheilinus undulatus Ruppell, 1835 (Labridae). Env. Biol. Fish. 62: 428.

Edrus, I.N., S. Arief, \& I.E. Setyawan. 2010. Kondisi Kesehatan Terumbu Karang Teluk Saleh, Sumbawa: Tinjauan Aspek Substrat Dasar Terumbu dan Keanekaragaman Ikan Karang. Jurnal Penelitian Perikanan Indonesia. 16 (2).

Edrus, I.N. \& I.E. Setyawan. 2011. Keanekaragaman Ikan Karang Perairan Belitung dan Pengaruh Kecerahan Air Laut. Jurnal Penelitian Perikanan Indonesia.( In press).

Edrus, I.N. 2010. Ikan Napoleon (Cheilinus undulatus Rüppell 1835) dalam Sorotan Dunia. Kertas Kerja. Seminar Konsultasi Publik. Sorong, Papua, Nopember 2010. KP3K-KKP.

Edrus, I.N. \& D. Suhendra. 2007. Sumber daya Ikan Karang. Dalam: Pulau 
Manterawu, Sumber daya Alam Pulau Kecil Teluar. S. Hartini \& G.B. Saputra (Eds). Penerbit Pusat Survei Sumber Daya Alam Laut, Bakosurtanal, Cibinong Bogor. $135 \mathrm{pp}$.

Fauzi, A. 2005. Kebijakan Perikanan dan Kelauatan: isu, Sintesis, dan Gagasan. Gramedia, Jakarta. 185 pp.

Gillett, R. 2010. Monitoring and Management of the Humphead Wrasse, Cheilinus undulatus. FAO Fisheries and Aquaculture Circular No. 1048, Rome. $62 \mathrm{pp}$.

Hopley, D. \& Suharsono. 2000. The status and management of coral reefs in eastern Indonesia. The Australian Institute of Marine Science for the David \& Lucile Packard Foundation, USA. 145 pp.

IUCN. 2006. Development of fisheries management tools for trade in humphead wrasse, Cheilinus undulatus, in compliance with Article IV of CITES. Final Report of CITES Project No. A-254 undertaken by the International Union for the Conservation of Nature and Natural Resources - World Conservation Union/ Species Survival Commission (IUCN/ SSC) Groupers \& Wrasses Specialist Group and led by Dr Yvonne Sadovy.

Michael, A.W. 2011. Cyanide and Dynamite Fishing, Who's really Responsible? Ocean N Environment Ltd. P.O. Box 2138, Carlingford Court Post Office Carlingford NSW 2118, Australia. email: oneocean@comcen.com.au. http:// www. Ocean NEnvironment.com.au. Diunduh dari http://www.eepsea.org. Juli 2011.

Pet-Soede L., H. Cesar, \& J. Pet. 1996. "Blasting Away: The Economics of Blast
Fishing on Indonesian Coral Reefs," in H. Cesar, ed., Collected Essays on the Economics of Coral Reefs, pp. 77-84.

Purnomo, H. 2009. Masalah Perikanan Napoleon. Kertas Kerja pada Forum Konsultasi Publik, Jakarta, September, 2009. KP3K - KKP.

Ruchimat, T. 2011. Usulan Inisiatif Status Perlindungan Jenis Ikan Napoleon (Cheilinus undulatus). Kerta Kerja pada Workshop FASILITASI PENETAPAN STATUS PERLINDUNGAN IKAN NAPOLEON (Cheilinus undulatus) di Hotel Blue Sky - Jakarta, 8 Juli 2011, KP3K - KKP.

Sadovy, Y., Kulbicki, M., Labrosse, P., Letourneur, Y., Lokani, P. \& Donaldson, T. J. 2003. The Humphead Wrasse, Cheilinus undulates: synopsis of a threatened an poorly known coral reef fish. Review in Fish Biology and Fisheries $13: 327-364$

Sadovy, Y. 2006. Napoleon Fish (Humphead Wrasse), Cheilinus undulatus, Trade in Southern China and Underwater Visual Census Survey in Southern Indonesia. Final Report: IUCN Groupers \& Wrasses Specialist Group. 25 pp.

Saputro, B.S. \& I.N. Edrus. 2008. Sumber Daya Ikan Karang Perairan Kabupaten Banggai, Sulawesi Tengah. Jurnal Penelitian Perikanan Indonesia. 14 (1): $73-113$.

Salm, R.V., J. Clark, \& E. Siirila. 2000. Marine and Coastal Protected Areas: A guide for planners and managers. IUCN. Washington DC. $371 \mathrm{pp}$.

Setyawan, I.E. \& I.E. Edrus. 2011. Struktur Komunitas ikan Karang di Empat Zona 
Perairan Kendari. Jurnal Penelitian Perikanan Indonesia.( In press).

Sim, S.Y. 2004. First Breeding Success of Napoleon Wrasse and Coral Trout. Magazine. Asia-Pacific Marine Finfish Aquaculture Network. Bangkok, Thaoland, April-June, No. 1.

Simatupang, P. 2003. Analisis Kebijakan: Konsep Dasar dan Prosedur Pelaksanaan. Jurnal Analisis Kebijakan, Edisi Maret: 14 - 35, Pusat Sosial Ekonomi Pertanian, Bogor.

Sumardiman, A. 2002. Peraturan Pembinaan Perlindungan Lingkungan
Suaka Perikanan terumbu karang. Buku Petunjuk. Kerjasama COREMAP dengan AusAID, Australian Government.

Tampubolon, S.A. 2011. Pemanfaatan Pengawasan Ikan Napoleon. Kertas Kerja Direktur Pengawasan Sumber daya Kelautan. DITJEN PENGAWASAN SUMBER DAYA KELAUTAN - KKP dalam Workshop : FASILITASI PENETAPAN STATUS PERLINDUNGAN IKAN NAPOLEON (Cheilinus undulatus) di Hotel Blue Sky - Jakarta, 8 Juli 2011, KP3K - KKP. 